\title{
Inequality and Emancipation : An Educational Approach
}

Dr. Stefan Gross*

All animals are equal. But some animals are more equal than others.

- George Orwell: Animal Farm

\section{Inequality and education}

Inequality is a fundamental experience in our social life. Two factors make it impossible to eliminate inequality entirely: first, the need for hierarchies of power in any political and legal system; second,

Abstract

Emancipation has lost its charisma. In the 1960s,

the term had been one of the saviour-concepts in the educational debate on social inequality and the political function of pedagogy in Western countries. Nowadays, as the discussion is still ongoing, the word is rarely in use. Overloaded with political enmeshments and a plurality of meanings, emancipation seems to be nothing more than a nearly forgotten relict of an ancient time. How could this rise and fall happen? The present essay is tracing the colourful history of emancipation in various contexts, recapitulating its pedagogical importance in the 1960 s and discovering how the pillars have kept their primary function, although the word is not in use any longer. the fact that there are natural inequalities of ability, enterprise and luck which affect people's course of life (Honderich, 1995, p. 406). Nevertheless, in the name of equality the reduction or amelioration of inequality seems to be one of the key-issues in contemporary social approaches in Western societies - no matter if they call themselves 'Marxist-humanist', 'neo-liberal' or 'critical'. A wide range of egalitarian concepts (Rawls, 2005; Dworkin, 1977; Sen, 1992) is giving suggestions how to minimize the social gap focusing either on an equalization of the different starting-possibilities (e.g. the 'welfare-state-concept' where a provision of social benefits is paid for by taxes) or by regulating the allocation of and the access to natural and social resources like water, electricity, health, education etc. However, all attempts seem to end in an anthropological vicious circle. "Left to themselves, some people will accumulate more wealth than others and use it to benefit their children, who will do the same" (Honderich, 1995, p. 406), thus establishing and broadening the gap between the upper and the lower classes.

Where these natural differences are turning into the reproduction of unjustified privileges, inequality is starting to become a threat to social peace. According to Francois Dubet, a French sociologist, in this context, the sensation of injustice is much more driven by personalized feelings than facts (Dubet, 2006). "Every society establishes therefore a hierarchic order of justified inequalities which allows everybody to get what he deserves according to his status" (Dubet, 2006, p. 21) defined by his position, age, sex, nationality

Trainer, Facilitator and Consultant, Neuland and PartnerDevelopment and Training, Germany 
$10 \mid$ Stefan Gross

or qualification. Nowadays the situation seems a paradox. Increased awareness of social inequality leads to the fact that we perceive more and more inequity in the world although we have developed comparably high equality standards in nearly all sectors of our society. Additionally, we live in a social and economic world, where the production of all kinds of inequality is a basic property. Previous unquestioned inequalities came under fire and left a climate of insecurity, disorientation and leadership vacuum.

Regarding this, the main question is not if we want inequality, but how we deal with it. Critical pedagogy is regarding this challenge as one of its core issues and has developed several concepts focusing on at least three different aspects. First, the empowerment of the underprivileged and oppressed (Freire, 1993), e.g. by starting literacy- and awareness-campaigns for adults (Freire, 1976). Second, the claim, that education has to play an important political role raising its voice against unjustified inequalities and avoiding their reproduction by "establishing the critical relationship between pedagogy and politics" (McLaren, 2006, p. 7). Third, located at the junction between the elder generation with members of the present society and a newcomer generation of 'world-starters', education has to be regarded as "the modality through which our culture presently reproduces itself" (Mollenhauer, 1983, p. 17). Hence, the question of equality and social justice can not only be seen as an arbitrary spare part but it is constitutive for pedagogy within its own structure. In addition to the social impacts, the educational situation itself - between an educator and the individual pupil - is asymmetric and basically determined by inequality according to power and competence, a difference that is manifested in the two processes of teaching on one and learning on the other side. Education comes to an end, where this previous constitutively asymmetric constellation is turning out in balance.

Regarding a critical approach, educational actions can therefore only be justified if the intervention is motivated by the idea that it will make the life of the child "somehow better: more complete, more rounded, more perfect - and maybe even more human. [...] It equips newcomers with the cultural tools needed for participation in a particular form of life and at the same time it secures cultural and social continuity. But we cannot be too naive about this, because these processes also contribute to the reproduction of existing inequalities - unwillingly or, in those cases in which education is utilized to conserve particular practices and traditions, also willingly" (Biesta, 2006, p. 2).

For those educators, emancipation became the term of critique and its conceptual history descriptively illustrates the reasons for a meteoric rise as well as the sudden fall.

\section{Emancipation}

Originally emancipation was a concept of the ancient Roman legal terminology. Through a ritual act, a son was released from the overall authority [patria potestas] of the father [pater familias]. The son was - ex manus capere ceremoniously taken out of the hand of the father and became a legal person and a self-reliant member of Roman civilization. The destination of the act was to acknowledge the independent status of the son by abolishing the representation through the father. After the biological birth this act can be regarded as a second 'social nativity' of the Roman as a citizen. Therefore, only those were emancipated by the father's hand who could assure the lastingness of the paternal property. In this early juristic understanding, emancipation was therefore a social act conducted by members of an already existing privileged social class - and it could be denied! The rulers appointed an elite selection of the younger generation to become successors. Thus from the beginning the execution of emancipation was always connected with social inequality and power.

Following the etymological development and 
adjustment of emancipation over the intervening centuries of Western history, three aspects are structurally remarkable:

First, starting as an intergenerative act with the conservative objective of integration in current social and legal conditions, emancipation turned into a political cry for a radical change. Paradoxically even when the masses fleeted the streets in the name of revolution during the era of Enlightenment in Europe and Northern America, hardly any qualitative upheaval succeeded. Reviewing the history of emancipative acts from the past to the present, ${ }^{1}$ most of these approaches followed an integrative mechanism of assimilation or failed in the long run. On the one hand, they allowed a liberalistic advancement of individuals and minority groups, who had been underprivileged in the past; on the other hand they did not harm the established inequality and injustice but even supported its reproduction. The son became an equal member of the society, slaves, Jews and women became free citizens - without being doubtful about the (un-)social order. Accordingly, Peter McLaren, one of the leading architects of contemporary critical pedagogy, describes the present crisis. The call for diversity and emancipation by politicians and educators seems to bring marginalized groups to the centre of society. In fact, for him this process of emancipation is only an action in terms. The only thing which is addressed is "the importance of addressing their [of underprivileged people, StG] needs, rather than actually addressing their needs, or addressing their actual needs" (McLaren, 2006, p. 49). Out of the pupation, the old principle is emerging again.

Second, the previous distinction between 'emancipated' and 'non-emancipated' members of a society disappeared and converted into a dynamic figuration with open end. The Roman law allowed a clear differentiation regarding the process from its final edge. Being emancipated was equal to having full civic rights. The semantic changes turned this original meaning into the opposite. Becoming a dynamic and transitive category (self-emancipation), emancipation gradually enlarged its target field to all sectors. Emancipation was everywhere and everybody - lords, farmers, children, civil men - seemed in need of being liberated from different chains. But in the same way, the process lost its destination. If each and everything could be linked with this idea, the term would become similarly meaningless.

Third, the dyad of an active father and a passive son was slowly substituted by a process of self-emancipation of large social groups and minorities. In the $17^{\text {th }}$ century, emancipation became one of the glittering political terms of the Enlightenment. Towards the dogmatism of the almighty church, individual emancipation was the embodiment of secularism and liberation from religious and civil conventions. In addition, it became a slogan with emotional appeal and pathos. Self-emancipation instead of waiting for liberation was the order of the day. Subject and object of the emancipative process merged.

After a period of latency, emancipation was reinvented during the 'Positivismusstreit', a typical German dispute between the Critical rationalists (Popper, Albert) and members of the Frankfurt School (Adorno, Habermas) about the methodology of the social science (Adorno, 1976).

\section{Emancipation and education}

Keeping the etymological heritage in mind, the term of emancipation evolved to a keyconcept of critical pedagogy in the 1960s. Following Juergen Habermas' inaugural lecture on 'knowledge and human interests' (Habermas, 1969), emancipation became the imperative for all sectors of social science with critical pretensions. In contradiction to the positivistic position of the Critical rationalism - focusing on a technical interest to predict and control - and as a supplementation to the humanities - trying to understand and interpret with a practical interest 
$12 \mid$ Stefan Gross

via (text-) hermeneutics - Habermas defined the interest of critical science as emancipatory. Its purpose is not "merely to understand situations, power and phenomena but to change them, to eradicate inequality. [...] The emancipatory interest subsumes the previous two interests; it requires them but goes beyond them" (Palmer, 2004 , p. 216). Its intention is transformative as it threatens the status quo in order to transform society and individuals to social democracy. Education epitomizes therefore a key-position, linking the older generation representing the establishment of contemporary social praxis with the newcomer generation.

Fulfilling the demands of an emancipatory interest to increase humanity in the social order, the educational praxis at this interface has to follow four principles.

(1) Connected with the attempt towards an equitable and human society there is a universalistic understanding of rationality (Habermas, 1976a). Therefore pedagogy has to prove its own premises and foundations via rational self-criticism. This rational approach helps to bring more transparency, enlightenment and rationality in educational action and praxis. Its immanent interest is to abolish the reification and self-alienation of man as a social being leading to a rational humanitarian society.

(2) The existing irrational axioms have to be eliminated out of pedagogical theory and educational praxis. The natural justified authority of mother/father, the legitimacy of violence in the educational relationship to extrude interests against resistance, the emotional allegory of maternal love for all pedagogical relationships (e.g. teacherpupil) - these backings of many educational concepts are stigmatized in the name of rationality as 'ideological' and 'irrational'. In the same way for Habermas and others, the positivistic attempt is insufficient, as its 'scientistic' and 'technicist' approach is neglecting the complexity of lifeworld [Lebenswelt] and the existing variety of interests (Palmer, 2006, p. 215). The bearing point of all critique is therefore bipartide; against rationality-blockade factors as well as parameters which do not help to resist. If pedagogy wants to be more than only a conservative apology of what has happened, it has to develop the progressive potential and capability in the growing young generation.

(3) Similarly, emancipation was regarded as a solution to the inherent normative problem existing in every educational situation. Pedagogy as an action-based science is the reflective theoretical counterpart to the educator in the praxis of real life. Instead of utilizing the physical or mental strength of the educator, "the strength of better arguments" (Habermas in Edgar, 2006, p. 45) should triumph in a discourse free of domination (Habermas, 1976b). Discourse is therefore the formal attribute of every communicative action in the field of education. In practical consequence, Klaus Mollenhauer, one of the intellectual fathers of critical pedagogy in Germany, subsequently claimed for a heterogeneous arrangement of educational environments with the chance of making different experiences in diversity instead of installing 'pedagogical provinces' in kindergarten and schools (Mollenhauer, 1969) In addition, the role of conflicts in the educational arrangement has to be redefined as not their prevention and suppression should be the focus of attention but a combined and common effort in finding a rational solution. Then, educational situations would obtain a much more serious instead of playing character.

(4) This concept in theory has to be completed by a practical turn down to earth to the reality of education. According to Bourdieu, every socio-historical formation develops a typical and unique habitus (Bourdieu, 
1977). This habitus describes the basic rules of the intercourse between the generations. It is rooted in cultural traditions as well as in requirements of the present socialframework. Critical empirical and structural research is therefore necessary to analyse options and limits for emancipation. These investigations can lead on a micro-level to a deeper understanding of communicative and interactive patterns in pedagogical situations. On a macro-level the role of social institutions, which are setting the framework for educational interactions, have to be analysed and reflected, as they are playing a fundamental role. Set up in order to structurally introduce the newcomergeneration to the established social-order, they are focusing on a continuation of the present status as well as on a betterment and upgrade. But on the other hand, they cement the existing inequality by allocating power and the monopoly of interpretation one-sided to the educators' generation. These attempts are critical in an emancipatory sense only if they refer to the social system in total. These social terms of conditions and institutions are determining even the scientific research. As a constitutive part these materialistic foundations have always to be reflected. Viewed in this emancipatory light, education is mainly reproduction with the productive annex of a contingent betterment.

\section{Political indoctrination and the cultural turn}

Soon after introducing the concept of emancipation to the pedagogic community in the 1960s in Germany, a polarised debate began.

Overnight, emancipation converted to one of the unifying key-ideas in the heterogeneous camp of critical theorists. Being a saviour-vocable and a scientific fashion-term at the same time, the application suffered the similar fortune like many others ${ }^{3}$ as its usage became excessive and inflationary. Everybody took it different and the semantic meaning was attached by its engagement and the context. Using emancipation in the educational field turned into a boundless endeavour.

Political instrumentalisations and infiltrations grew and made it easy for the positivistic and conservative forces to blame the idea of being politically indoctrinative, overthrowing and dangerous for the social stability. The frontiers between politics and pedagogic became blurred and any use of the term turned to a seemingly impossible undertaking. Emancipation became a forgotten concept in almost the same manner as it emerged.

Once more, it was Klaus Mollenhauer's merit that the emancipatory roots have not been lost for the educational discussion in Germany but were recovered as "forgotten connections" (Mollenhauer, 1983) in the 1980s. Not in a content-based way, but with a problem-focused entry Mollenhauer is raising the old question if there do exist "fundamental elements in present pedagogical concepts, a minimum standard of problems which cannot be ignored by anyone who wants to educate responsibly no matter at which position of our education-system (s) he is involved?" (Mollenhauer, 1983, p. 16). During his search for an answer he defined the main job for educationists to re-contextualize pedagogical problems in the cultural framework and to raise awareness among the adult-generation for an open discussion on educational issues. As education does not follow mechanical rules and is therefore neither predictable nor feasible but a dynamic interaction in a complex of various influencing factors, the character of pedagogical knowledge is not more than prognostic ex post (Mollenhauer, 1983). The size of the issue is too large to gain definite knowledge in advance.

Concerning emancipation Mollenhauer modified his previous foundations accordingly - of course with a careful avoidance of the ' $e$-word' to prevent the resurgence of academic fights.

(1) Challenged by the popular movement of 
14

Anti-pedagogy (Oelkers, 1983), he initiated an educational debate on the reassurance of our tradition, history and lore. If we want to prepare our children for an uncertain future, we have to start a cultural self-reflection regarding those parts that are worthy to be sustained in the name of continuation and innovation. As history is not a linear process and education always runs the risk of failure, a perpetual recapitulation is indispensable. Future needs tradition. Emancipation could be a key-word to remember this mission in a critical and conservative sense.

(2) As critique has the tendency to be onesided negative, Mollenhauer focused an affirmative access in his later writings. The first step towards an adoption of the cultural and social achievements by the newcomergeneration should be confirmation instead of uncertainty. While political action is always trying to enforce the protagonist's interest - even against the will of the opponent - educational action in an emancipatorical understanding has its fortune in making the educator redundant. Therefore, the way how we invite children and youngsters to become a part of our society has to be reasonable and disputatious - including the risk of being refused. Accordingly, the educational task for the elder generation is to present the structure of our life-world ingeniously and meaningfully, if not for us, at least for our children. The long-standing concept of emancipation is preserving this heritage from the past to the present.

(3) In allegory to Paul Watzlawick's famous axiom (Watzlawick, 1962) we cannot not educate children as we always present and re-present a certain way of life. This kind of presentation will only be responsible if we ask ourselves critically, what way of life we do present to children by living with them and what way of life ought to be systematically represented to children in schools and educational institutions. These questions are not only a call for self-reflection of the educators' generation but move the spotlight to the children's side; what do they need for their future lives, when we are supposed to be already gone? Emancipation might help to detach oneself from the educators' unilateral view-point and take both sides of the process in consideration equally - presentation and representation of our current heritage as well as developmental preparedness and the self-starting competence of children (Mollenhauer, 1983). Accordingly the task for pedagogical theory is to get a broad idea of children's consciousness and world outlook.

(4) Like every theory of a social praxis, pedagogy cannot ignore the political influencing factors without becoming either ideological or inadequately simplified. To avoid political indoctrination, pedagogy has to reflect its dependency and its coordination with politics and other neighbouring disciplines permanently. It is because of its own deserved development in the past, that the concept of emancipation has the ability to remind of this risk.

\section{Conclusion and outlook}

The usage of a term across the borders of scientific fields is a venture. On the one hand, it offers the opportunity to discover new aspects, neglected connections or so far hidden interdependencies. Subject-specific awareness is raised and challenged with every new word-appearance in a so far closed context. On the other hand, it might happen that previous coherences and thoughts are overwhelmed and a subject is loosing its connection to its basic questions. Exactly this dual character signifies the multiple usage of emancipation in the pedagogic field.

What does emancipation mean regarding the relationship between parents and their children - for each of the both sides as well as for their 
intergenerational relation and cooperation? How can we bring this process to an end, how do we arrange the circumstances for the transition, starting from a passive 'going-to-beemancipated' leading finally to an act of reflected and conscious self-emancipation? Where are possible barriers and hindrances on the way for this act of liberation?

Due to the efforts of critical theorists in the past and today the interdependency and co-existence of pedagogy and politics are exhaustively analyzed and described. Emancipation played a key-role in these reflections in the 1960s and will undertake the task of critical reflection in future, too, if the term finds its way back into the educational debate. Regarding the shifting of key-vocabulary we are witnessing not only politics as a gatecrasher. As in all parts of our life, economical reasons have taken the lead in defining, judging and displacing primal coreconcepts in a capitalized world. The 'permanent ecomonic tribunal' (Foucault) installs a new way of looking at education and at what counts in education with the risk that education may be "reduced to a sub-sector of the economy - a zone of free capital investment" (McLaren, 2006, p. 224). Where this kind of 'hostile takeover' will lead to if we are not able to build up "robust reflexivity" (Harding, 1998) can be learnt in a critical review of the history of emancipation as an educational approach.

\section{Endnotes}

1) After extending the target group of individuals to commendable slaves and women, larger groups and minorities started their vote for an emancipative change. Beginning with liberalism movement towards religious toleration ( $17^{\text {th }}$ century), the anti-slavery act was another milestone in history (1776), followed by the abolition of the Ancient Regime by the French Revolution (1789) and leading to the selfemancipation of women in Europe (1850). Nevertheless, the establishment was hardly touched. After a short period of latency, the old rulers came back into power. Inequality obtained again. Regarding religious, ethnic, gender and political aspects, most of these emancipative acts are still waiting for their completion.

2) Started with single movements in the $17^{\text {th }}$ century, emancipation became a political category in the age of the European Revolutions. The famous introduction to Jean-Jacques Rousseau's Social Contract is considered as a brief definition of this new understanding, focusing on both: a philosophical explanation combined with a call for political implementation: "Man is born free; and everywhere he is in chains. [...] Were I to consider only force and the effect that flows from it, I would say that so long as a people is constrained to obey and does obey, it does well. For by recovering its liberty by means of the same right that stole it, either the populace is justified in getting it back or else those who took it away were not justified in their actions." (Rousseau, 1987, p. 141)

Later Karl Marx described in his 1843 written essay 'On the Jewish question' the interdependency of religion, state and society concluding: In the final analysis, "the emancipation of the Jews is the emancipation of mankind from Judaism" (Marx, 1976, p. 377). Religious and political emancipation are unified. In his later 'Contribution to the critique of Hegel's philosophy of right' Marx added pragmatically: "The head of this emancipation is philosophy, its heart the proletariat. Philosophy cannot realize itself without the transcendence [Aufhebung] of the proletariat, and the proletariat cannot transcend itself without the realization [Verwirklichung] of philosophy (Marx, 1976, p. 391).

3) Regarding the short history of rises and falls of concepts like 'maturity', 'bumanity', 
16

self-help'in the pedagogical context. Recently one can observe similar developments regarding the term 'sustainability'.

\section{References}

Adorno, T. (1976). The positivist dispute in German sociology. London: Heinemann.

Biesta, G. (2006). Beyond learning: Democratic education for a human future. Boulder and London: Paradigm Publishers.

Bourdieu, P. (1977). Outline of a theory of practice. Cambridge: Cambridge University Press.

Dubet, F. (2008). Ungerechtigkeiten: Zum subjektiven Ungerechtigkeitsempfinden am Arbeitsplatz. Hamburg: Hamburg Edition

Dworkin, R. (1977). Thephilosophy oflaw. Oxford and New York: Oxford University Press.

Edgar, A. (2006). Habermas: The key concepts. London and New York: Routledge.

Freire, P. (1976). Education: The practice of freedom. London: Writers and Readers Publishing Co-operative.

Freire, P. (1993 [1970]). Pedagogy of the oppressed. London: Penguin.

Habermas, J. (1969). Technik und Wissenschaft als 'Ideologie'. Frankfurt: Suhrkamp Verlag.

Habermas, J. (1976a). A positivistically bisected rationalism, in: Adorno, T. (1976).

Habermas, J. (1976b). Legitimation crisis. London: Heinemann.

Harding, S. (1998). Is science multicultural? Postcolonialisms, feminisms and epistemologies. Bloomington and Indianapolis: Indiana University Press.
Honderich, T. (1995). The Oxford companion to philosophy. Oxford and New York: Oxford University Press.

Marx, K. (1976). Karl Marx Friedrich Engels Werke. Band 1. Berlin: Dietz Verlag.

McLaren, P. (2006). Rage and hope: On war, imperialism and critical pedagogy. New York: Peter Lang Publishing.

Mollenhauer, K. (1969). Erziehung und Emanzipation: Polemische Skizzen. Munchen: Juventa Verlag.

Mollenhauer, K. (1998 [1983]). Vergessene Zusammenhänge: Ueber Kultur und Erziehung. Weinheim and Munchen: Juventa Verlag.

Oelkers, J. (1983). Antipaedagogik: Herausforderung und Kritik. Braunschweig: Agentur Petersen.

Orwell, G. (2002). Animal farm. London: Penguin Classics.

Rawls, J. (2005 [1971]). A theory of justice. Harvard: Harvard University Press.

Rousseau, J. (1987). The basic writings. Discourse on the science and the arts. Discourse on the origin of inequality. Discourse on political economy. In $O n$ the social contract. Indianapolis: Hackett Publishing.

Sen, A. (1992). Inequality re-examined. Harvard: Harvard University Press.

Watzlawick, P. (1962). Pragmatics of human communication: A study of interactional patterns, pathologies and paradoxes. New York: W.W. Norton \& Company. 